\title{
Diversity of Agroforestry Species and Uses in Two Ecological Regions: A Case from Central Nepal
}

\author{
Hari Prasad Pandey $\mathbb{D D}^{1}{ }^{1}$ Narayan Prasad Pokhrel, ${ }^{1}$ Dol Raj Luitel, ${ }^{2}$ Kamal Acharya, ${ }^{3,4}$ \\ and Kabita Kumari Shah (iD ${ }^{5}$ \\ ${ }^{1}$ Ministry of Forests and Environment, Singha Durbar, Kathmandu, Nepal \\ ${ }^{2}$ Department of Plant Resources, Kathmandu, Nepal \\ ${ }^{3}$ Division Forest Office, Sindhuli, Bagmati Province, Nepal \\ ${ }^{4}$ School of Forest Sciences, University of Eastern Finland, Joensuu, Finland \\ ${ }^{5}$ Department of Plant Science, Pennsylvania State University, University Park, State College, PA 16802, USA
}

Correspondence should be addressed to Hari Prasad Pandey; pandeyhp123@gmail.com

Received 24 July 2021; Revised 28 September 2021; Accepted 9 October 2021; Published 31 October 2021

Academic Editor: Chunpeng Wan

Copyright ( $\odot 2021$ Hari Prasad Pandey et al. This is an open access article distributed under the Creative Commons Attribution License, which permits unrestricted use, distribution, and reproduction in any medium, provided the original work is properly cited.

\begin{abstract}
Multiple benefits of the agroforestry systems attract the attention of the global community and are being practiced in Nepal from time immemorial. However, there is minimal evidence of the diversity of species and the use value of plants and their comparative analysis in ecological regions. This study compares the diversity and use value of plants grown in the agroforestry system (home garden) in two separate ecological regions in central Nepal. The frequently used diversity indices were used to measure species diversity. A total of 130 and 99 species, 96 and 69 genera, and 50 and 40 families were reported from home gardens in the Terai and midhill ecological regions, respectively, where 58 species were common for both. The findings reveal Terai farmer prefers ornamental plants over fruit and fodder in the midhills indicating that horticulture and livestock-based livelihood could be enhanced in the hilly region. The diversity indices indicate a higher diversity of plants in the Terai region than in midhills. However, Mann-Whitney $U$ test showed an insignificant difference in species diversity between the regions. Moreover, the chisquare test revealed that there is no significant variation in the use diversity for the regions. The results demonstrate similar plant diversity in the home garden despite the difference in ecological regions and species varieties. The finding assists in understanding the composition of biodiversity in agroforestry systems in specific areas of two different ecological zones and provides insight into the agroforestry for species preferences and use-related decisions. Future research with established management procedures may be required to confirm these findings and provide agroforestry establishment criteria for agricultural sustainability.
\end{abstract}

\section{Introduction}

The agroforestry system is being practiced throughout the globe due to its multiple benefits in many aspects. Nepal is an agrarian-economy-based country, where people have been growing plants (both crops and woody species) in their home gardens, from time immemorial especially in rural areas where the majority (more than two-thirds) of the population still reside in the countryside[1]. Plants in the home garden provide different goods and services to the household, communities, and the environment. In all agroforestry systems, there are only three fundamental sets of components that are managed by people, i.e., woody perennials, animal husbandry, and herbaceous plants (both wild and domesticated crops). These components are a first step in classifying the agroforestry systems as agrisilvicultural systems based on their composition [2]. The integration of different plant communities offers a wide range of opportunities for synergy [3], from economic, social, and environmental benefits to structural and functional interrelationships between and within communities [4]. Trees in the farmland also help to control weeds and additional 
nutrients in return from crops [5]. Besides, the agroforestry system provides various niches within the farm where trees provide products and nutrient cycling for agricultural products and agriculture crops micronutrients in return. This combination of vegetation assembly forms with a relatively high level of niches, thereby having high diversity within the small area [3].

Integrated agriculture with trees and livestock is a common practice in Nepal. This boosted biodiversity facilitates the excellent avenue of ecosystem services to creatures, including human beings [6]. Agroforestry systems play a significant role in deriving financial returns and environmental and socioeconomic benefits $[7,8]$ by addressing broad problems like enhancing the financial and health benefits to the local people [9], facilitating biodiversity [5], and surmounting soil erosion and endorsing soil fertility for the sustainability of the hill farming system [10-13]. This is because farmers prefer agroforestry trees that are fast-growing and climatically appropriate, as well as short-rotation trees [14]. The role of agroforestry systems in the conservation of biodiversity and the consumption of rural households in private hill land areas is biologically and socially more complex than that of other degraded land systems [15]. This is due to the cultivation of fodder or fruit trees in an intricate mosaic or conglomeration along with crops planting [16]. Therefore, understanding such agroforestry systems from different ecological regions would provide insight for plausible decision-making to enhance the systems across the regions.

A common type of agroforestry systems is home garden. The home garden is a confined piece of land cultivated with a variety of annual and perennial crops on which a house is built [17] and is a type of agroforestry, namely, agrosilvicultural system [2]. In combination with annual and perennial farming crops and small livestock inside house complexes, home gardens are distinguished by numerous plant strata composed of trees, shrubs, and herbs [18]. This bridges social and biological components, integrating cultivated species with the restoration of components and genetic diversity of natural habitats within a defined area [19]. Some explorations of multiple benefits of agroforestry are in place. Some of them are in a global level $[20,21]$ and few notable types of research on agroforestry in Nepal were done by Khadka [22], Khanal [16], Dhakal et al. [23], Amatya et al. [24], and Paudel et al. [25]. Conversely, as the home garden of two ecological regions of central Nepal, assessing the diversity along with its instantaneous use and benefits to the local people from plant species of agroforestry is poorly understood. In this context, this study attempts to assess the species diversity and use value of the agroforestry system from two ecological regions of central Nepal taking the case of a home garden. Therefore the findings of the present study fill the knowledge gap on agroforestry species diversity and they are immediately used by local farmers from two different ecological regions. The findings would be a reference for the plausible decision-making for advancing agroforestry systems in different ecological regions without jeopardizing livelihood options for socioeconomical, ecological, and environmental benefits.

\section{The Study Area}

The study was carried in the Bahigaon Village of Chhatradev Rural Municipality and the Bodgaon Village of Banganga Municipality of Arghakhanchi and Kapilbastu districts of midhill and Terai regions of central Nepal, respectively (Figure 1). These municipalities were selected purposively based on a good number of home garden practices and their utilization compared with the other municipalities of the regions. The districts are consecutive but belong to distinct ecological regions, thereby the study sites belong to different zones. This attribute would facilitate making a reasonable comparison of the ecology within the same landscape.

2.1. Chhatradev Rural Municipality. Chhatradev Rural Municipality lies in $28^{\circ} 00^{\prime}-28^{\circ} 01^{\prime} \mathrm{N}$ and $83^{\circ} 13^{\prime}-83^{\circ} 34^{\prime} \mathrm{E}$ at the north-east belt of Arghakhanchi district (Figure 1). The altitude ranges from $720 \mathrm{~m}$ to $1780 \mathrm{~m}$ a.s.l. (above sea level). The whole area of this rural municipality falls in the midhills region. Major ethnic groups inhabiting the area are Brahmin, Chhetri, Magar, Newar, Kami, Damai, and Sarki. The Chhatradev rural municipality has a subtropical type of climate. Major vegetation includes the Schima-Castanopsis forest with associated species of Pinus roxburghii, Myrica esculenta, Alnus nepalensis, Ficus species, and Madhuca longifolia. The temperature ranges from $14.9^{\circ} \mathrm{C}$ to $25.8^{\circ} \mathrm{C}$ and the average annual rainfall is $1627.7 \mathrm{~mm}$ [26].

2.2. Banganga Municipality. The Banganga Municipality lies in $27^{\circ} 35-27^{\circ} 48^{\circ} \mathrm{N}$ and $83^{\circ} 03^{\prime}-83^{\circ} 14^{\prime} \mathrm{E}$ at the north-east belt of Kapilbastu district. The altitude ranges from $100 \mathrm{~m}$ to $350 \mathrm{~m}$ a.s.l. The area of this municipality belongs to the Terai region. Major ethnic groups residing in the area are Brahmin, Chhetri, Gurung, Magar, and Tharu. The vegetation of the area is dominated by riverine deciduous forest with Dalbergia sissoo and Bombax ceiba species. Other major tree species include Shorea robusta, Leucaena leucocephala, Artocarpus lakoocha, Morus alba, and Artocarpus heterophyllum. Banganga Municipality has a hot and humid climate during the summer and cold during the winter. The temperature ranges from $18^{\circ} \mathrm{C}$ to $30.3^{\circ} \mathrm{C}$ and the average annual rainfall is $1532.0 \mathrm{~mm}$ [26].

\section{Material and Method}

3.1. Sampling Design. The field inspection was made in October-November (2019) because the season was gloomy and the leaves and flowers on almost all vegetation can be easily recognized. Moreover, people used to assemble at that season for the festival, which also permitted the researcher to get support from locals for the data collection. A list of household was prepared with the consultation with key informant (school teacher and lead farmer-for both sites), and the required sample size was estimated. For use-value identification, the household was surveyed that fell in the sample list with a semistructured questionnaire, and the vegetation analysis was carried out on the respective household's farmland-home garden. Simple random 


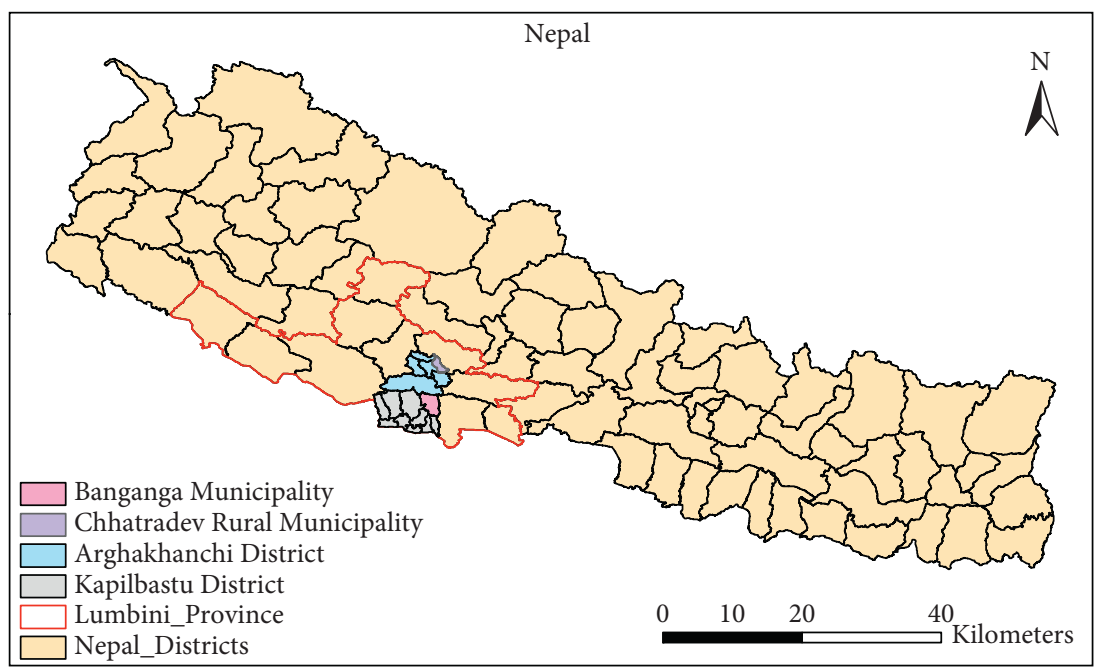

(a)

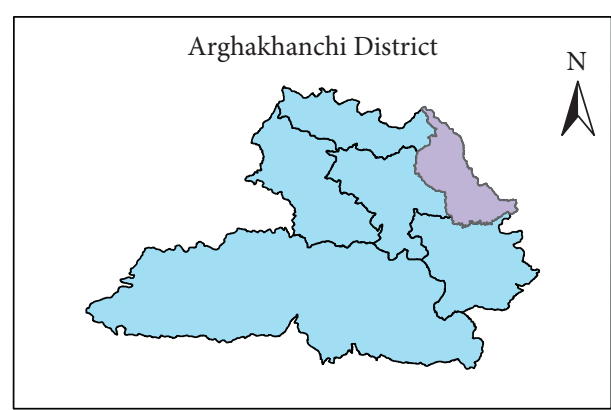

(b)

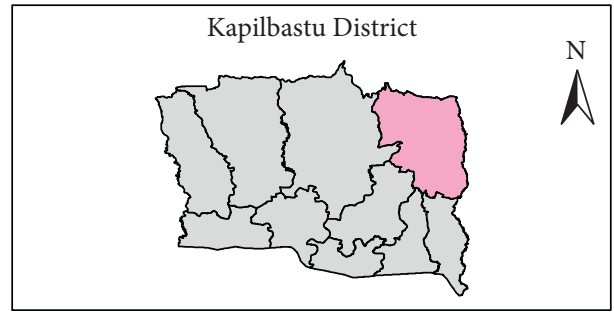

(d)

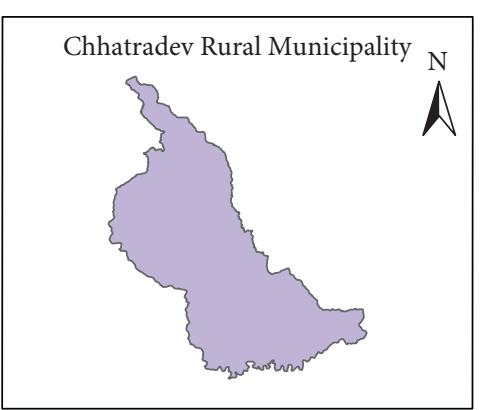

(c)

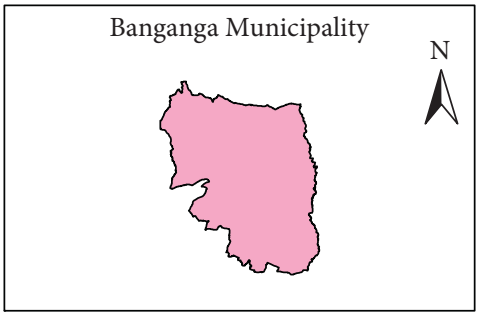

(e)

FIgURE 1: Maps showing the study area. (a) Map of Nepal showing study area; (b) Arghakhanchi district; (c) Chhatradev rural municipality; (d) Kapilbastu district; (e) Banganga municipality.

sampling was applied to cover the composition of the species in the home garden. A single household and its home garden is deemed to be a sample for both use-value documentation and species diversity analysis. For vegetation analysis, a participatory approach was adopted to ensure that the sample plotscan cover both agriculture and woody species in the home garden.

3.2. Data Collection. A participatory approach was adopted in data collection and plant identification. Information about home garden, the composition of the species, and the use-value of each household was collected through a semistructured questionnaire. A set of semistructured questionnaires were developed following the recently published secondary literature. A total of 80 questionnaires were commissioned. There were two parts to the questionnaire, first part included the question to depict the socioeconomic information of the home garden owner and the second part included the questions to list out the species diversity and their use values.

For the home garden assessment, a square quadrant of $20 \mathrm{~m} \times 20 \mathrm{~m}$ each was laid in the sampled household's home garden and accounted for vegetation of both woody species and agricultural species. A total of fifty (50) households out of one hundred fifty (150) and thirty (30) households out of two hundred (200) households were taken from the midhill and Terai regions, respectively. These disproportionate sampling sizes were recommended to reduce the bias in sampling due to the higher microclimatic variation in the midhills to that of the Terai region, which mainly governs the vegetation in the locality [27]. Local people voluntarily participated to identify 
the species-both woody and agricultural-to examine the woody species diversity since the agriculture crop may vary with season and household preferences. The relatively age-old ( $>40)$ farmers were purposively selected for a semistructured questionnaire survey to assess the prime and traditional use of the particular species that grow in the agroforestry system [4]. Uncovered and unrecognized information on vegetation diversity and use value was complemented by informal discussions and questionnaire checklists with local farmers. This checklist was also used to retrieve qualitative information from the owner's home garden for evaluation and classification of the diversity of use of the species grown in their home garden. Moreover, the researchers (authors) group was itself a composition of local inhabitants, foresters, agriculture scientists, and plant taxonomists themselves involved in data collection so that it felt easy for plant identification and primary use-value recognition. Plant species cultivated in home gardens and irrigated and nonirrigated land held by farmers for multiple purposes were enumerated and crossvalidated with the aid of the respondents' responses on the checklist and informal conversations.

3.3. Data Analysis. The data collected from the field were edited, coded, and decoded before for analysis. Species composition, genera, and family level comparisons were made through graphical presentations. Primarily, eight groups of user diversity were categorized and classified accordingly. Despite the fact that a plant had multiple use values for a single species, the study considered the farmers' primary use of the plants. Using the Mann-Whitney $U$ test in R statistical package [28] and MS Excel, species diversities were tested. The Mann-Whitney $U$ test is a nonparametric test such that the probability of a randomly selected value from one population is less than a randomly selected value from a second population. For the unequal sample size, this test investigates whether two independent samples were selected from populations having the same distribution. The Mann-Whitney $U$ test is often used when the assumptions of the independent samples $t$-test are violated [29]. The frequency of species' utility in different categories between two different regions is tested using the Chi-square test.

3.4. Diversity Estimation. The diversity of plants refers to both the number of species and their frequency (abundance). The crops are temporary and have a wide variation in seasons and species types, also clustered in a bunch (e.g., paddy), which creates a very difficult situation for diversity analysis. Therefore, this study only considered the diversity of woody species grown in the home garden for diversity index analyses. However, comparative use diversity, genuswise diversity, family-wise diversity, and species-wise diversity for the regions were considered to be both agriculture and woody species. The species diversity was analyzed by using the Shannon index, Simpson index, and Biodiversity index as follows.

3.5. Shannon's Index. The following relation is used for Shannon index diversity analysis:

$$
\text { Shannon } \operatorname{index}(H)=-\sum p_{i} \operatorname{Ln}\left(p_{i}\right) \text {, }
$$

where $p_{i}=$ proportion $(n / N)$ of individuals of one species found $(n)$ to the total number of individuals found $(N)$ and Ln = natural log; $\square=$ sum of the calculation. A typical value of $H$ is generally between 1.5 and 3.5 in most ecological studies, and the index is rarely greater than 4 . The Shannon index increases as both the richness and the evenness of the plant community increase [30].

3.6. Simpson's Index. Since evenness and dominance are simply two sides of the same coin, their measures are complimentary. Simpson's index is based on the probability of two individuals drawn at random from an infinitely large community belonging to the same species [30]. Mathematically,

$$
\text { Simpson index }(D)=\frac{1}{\sum p_{i}^{2}},
$$

where $p_{i}$ is the proportion of individuals found in species $i$ for a finite community; this is Simpson index $(D)$ for finite population $=N(N-1) /(\square n(n-1))$.

Symbols have their usual meaning as defined above. Simpson's diversity index is a measure of diversity that takes into account the number of species present, as well as the relative abundance of each species. As species richness and evenness increase, so the diversity increases. The value of $D$ ranges between 0 and 1 [30].

3.7. The Biodiversity Index. The biodiversity index was calculated by the following relation as used by Magurran [31]:

$$
\text { biodiversity index }(\mathrm{BI})=\frac{(\text { the number of species in the area })}{(\text { the total number of individuals in the area })} \text {. }
$$


The aforementioned indices are very popular because of their simplicity, and the sample size has little impact on the indices $[32,33]$.

\section{Result}

4.1. Floristic Composition. A total of 130 and 99 plant species were found in Banganga (Terai) and Chhatradev (midhills) region, respectively. There were 58 common species, and 72 and 41 species are unique for Terai and midhills, respectively (Figure 2). Out of 130 recorded plant species in the Terai region, only 35 species were woody plants. Similarly, in midhills, only 30 species were trees out of 99 plant species. The rest of the species were nonwoody, of agriculture-related plants.

4.2. Species Diversity. The study found 99 species in midhills and 130 species in the Terai region of Nepal (a total of 171 species), among which a total of 140 genera were identified (Figure 3 ). The genera containing numbers of species range from 1 to 5 species. The genus Ficus in midhill region and the genus Brassica in the Terai region have 5 species belonging to them, which are the largest genera from the study sites. The analysis showed that 69 genera in midhills and 96 genera in the Terai region have only one species. In both regions, 7 genera have 2 species each. The genus Prunus has 3 species, Brassica and Citrus, which have 4 species in each in the midhills, while 5 genera of the Terai region have 3 species belong to each genus (Figure 3).

Similarly, a total of 50 families in Terai and 40 families in midhills were found in the study area. Among these, 21 families in midhills and 22 families in Terai have single species in each family, whereas a single family having 15 species is the biggest family from Terai (Figure 4).

Similarly, 6 families of midhills and 8 families of Terai region have 2 species and 3 families of midhills and 9 families of Terai region have 3 species, belonging to those families (Figure 4). Moreover, 3 families of midhills and 2 families of the Terai region have 4 species belonging to them. The family Brassicaceae in the midhills has 5 species, while 6 families of the Terai region have 5 families; 3 families of midhills and 2 families of Terai region have 6 species belonging to these families. The families Cucurbitaceae and Moraceae have 7 species, whereas the family Poaceae has 8 species in the midhills. The family Fabaceae has 15 species in the Terai region $(\mathrm{S} 1)$.

4.3. Utilization Diversity of Agroforestry Species. The variety of uses for all species (171) is classified into eight broad categories based on the primary use of the species such as cereals and pulses, ornamental, vegetable and pickle, fodder and timber, fruit, traditional/religious, and pharmaceutical use. In the midhill region, fruit plants and plants used for rendering vegetables and pickles have the largest variety of uses. Similarly, thirty-five plant species have been reported for ornamental use in the Terai region (Figure 5). Our finding indicates the use value of plants in midhills has more

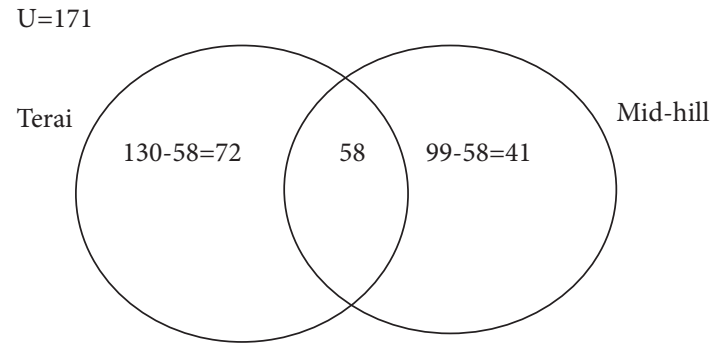

FIgURE 2: Number of plant species in the midhills and Terai regions.

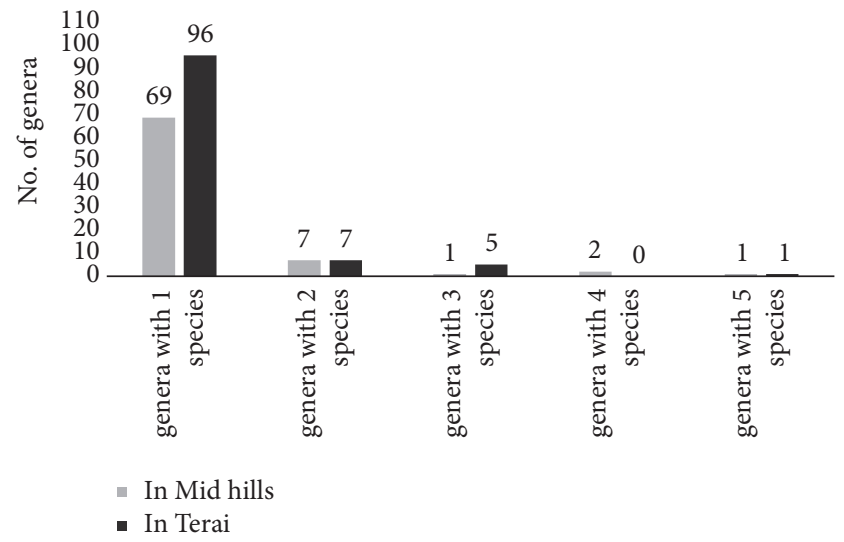

FIgURE 3: The genera-wise species distribution in the study area.

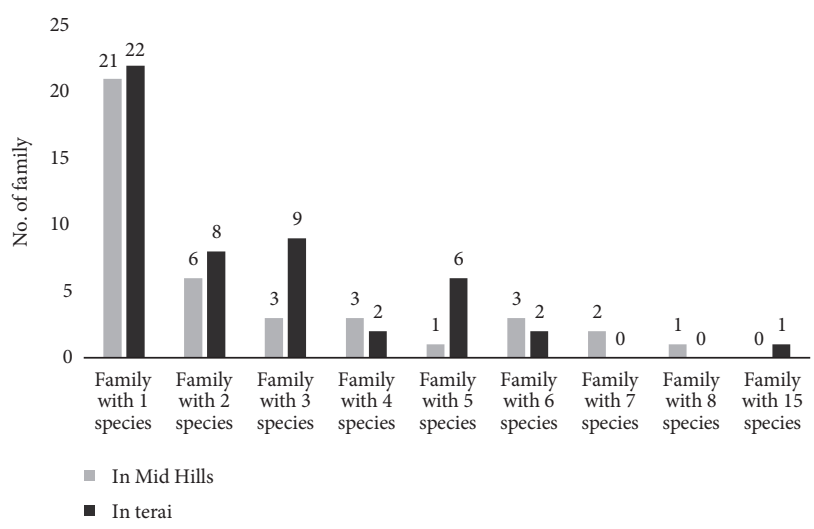

Figure 4: Family-wise species distribution in the study area.

focus on horticultural plants compared to ornamental diversity of the Terai region in central Nepal (Figure 5).

In the Terai region, the highest variety of plant species (species richness) was grown as of ornamental category while the least variety was found in cereals and pulses as well as medicinal application (Figure 5). Likewise, in the midhills region, most of the plants were grown for fruits and vegetable varieties, and the least was occupied by medicinal and traditional/religious uses (Figure 5). Despite species are governed by the site ecology and tradition as per the custom of the people, we have tested whether or not the number of species varies by site and utilization categories statistically. The chi-square test showed that there is no significant 


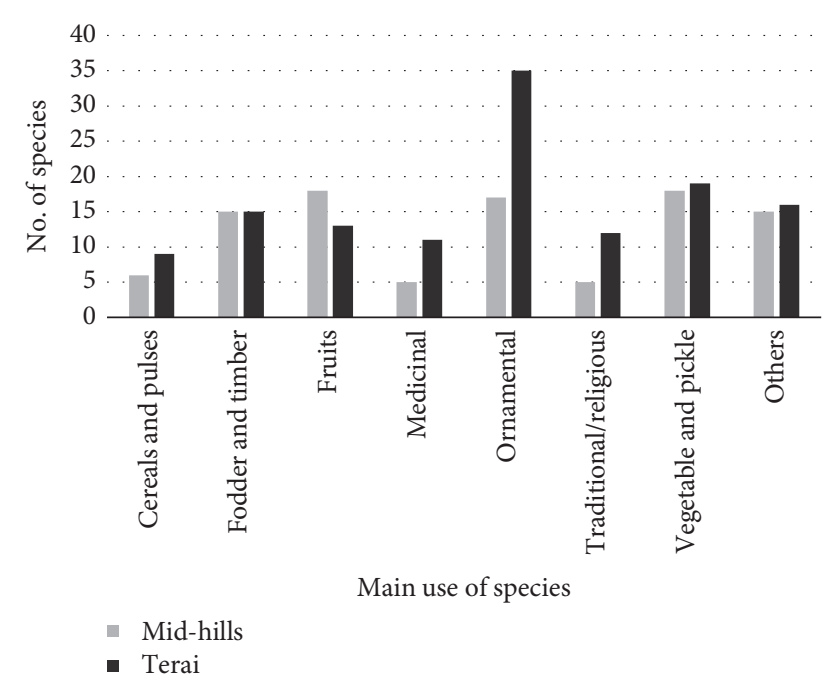

FIgURE 5: Use diversity of species in two ecological regions of central Nepal.

difference $(p=0.2678)$ at a $5 \%$ significant level between regions and utilization categories of the species in the home garden This result indicates that the utilization diversity of species in terms of number in the agroforestry system in midhill and Terai ecological regions is similar.

The frequently growing tree species at the home garden in Terai were Artocarpus lakoocha, Leucaena leucocephala, Mangifera indica, Psidium guajava, Litchi chinensis, Phyllanthus emblica, Polyalthia longifolia var. pendula, and Azadirachta indica. While in midhills, frequently grown tree species were Brassaiopsis species, Ficus semicordata, Litsea monopetala, Grewia optiva, Ficus nemoralis, Citrus reticulate, Ficus clavata, Ficus lacor, and Prunus persica. The details of individual plant species, their respective families, local names, botanical names, and the local user have been presented in Annex S1.

4.4. Diversity Indices. Results showed Shannon's index values of 1.24 and 1.21 for Terai and midhills, respectively (Figure 6). Similarly, Simpson's index was found as 0.091 for Terai and 0.087 for midhill region (Figure 6). The statistical test showed insignificant outputs $(p>0.05)$ between the regions in terms of Shannon and Simpson diversity indices of the woody species. Meanwhile, BDI was found at 0.140 and 0.132 for Terai and midhill regions, respectively.

The analysis of diversity (Figure 6) is based on 30 woody species from midhill and 35 woody species from the Terai region. The diversity indices and test results indicate that Terai and midhills have almost similar species diversity. Although the species diversity is similar, species composition observes dissimilarities in the two ecological regions (Figure 2).

\section{Discussion}

The study found a total of 130 species in Terai and 99 species in midhill in which 58 species are common in both regions. A similar study has reported 165 different crop species in

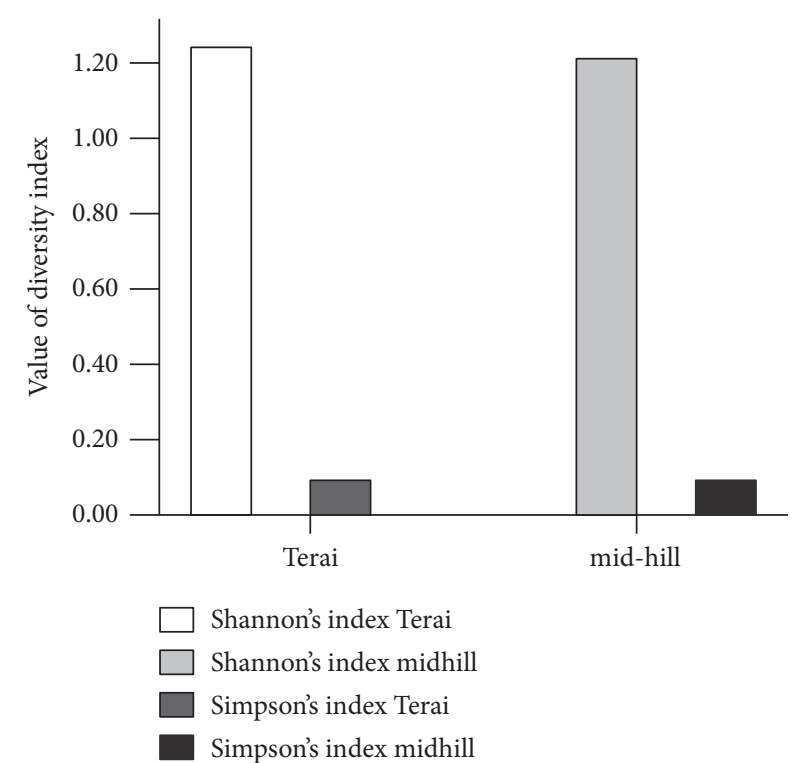

FIgURE 6: Diversity indices of plant species in Terai and midhill regions.

Terai and midhills in Nepal [34], 71 tree species have been reported in the home garden of India [35], and 45 tree species have been reported in the home garden of Indonesia [36]. Due to the substantial variance in the climatic and elevation ranges, comparatively higher species are present in this study area. It implies that there are more opportunities for improving the preference of agroforestry species accessible to both ecological regions in Nepal for agricultural diversification and climate mitigation by local actions (tree planting in and around farmland) without undermining food security. This study revealed that there was a higher number of species in Terai in comparison to the midhills region (Figure 2). The results disagreed with the findings of Sunwar [34] but were consistent with that of Arnold and Perez [37]. The reason behind the higher number of species in Terai may be because the study was conducted in the home garden and the agroforestry practice linked with the space available for introducing new species in the home garden. This means having more space and all available land can be utilized in Terai; however, utilizing all available land is not possible to grow plants in midhill land due to topography [27] and moisture deficiency [38]. In other words, in Terai, the area of the home garden or land owned per household was larger, allowing for the integration of diverse species into agroforestry practices. This finding indicates that due consideration is required for species selection in the midhills to advance the home garden's benefits ecologically and economically.

The warm, humid climate and longer soil moisture retention of the Terai region might facilitate the growth of varieties of plants like Polyalthia longifolia var. pendula, Murraya paniculata, Amomum subulatum, Punica granatum, Melia azedarach, Cicer arietinum, and Garuga pinnata which are natural to the Terai, resulted in higher diversity of plant species, as noted. These species are some example species of tropic-climate lovers. Genera and family-wise 
species distribution is presented in Figures 3 and 4 respectively which are relatively diverse in Terai than the midhills. Similar observation reported from Ethiopia that local farmers practice multistory agroforestry systems especially for coffee production in the plain area [3]. Because the Terai region has a greater number of species than the midhills region of the research area, the associated genera and families are also more abundant. This result indicates that the Terai region could be a better place to introduce new species in an agroforestry system as a pilot site for most of the species. The insignificant outputs of diversity and species diversity between the ecological regions were obtained (Figures 5 and 6). This indicated that there were almost similar proportions of species used as cereals, pulses, medicinal, and traditional uses. In corroboration with this finding, the farmers use diversified cropping patterns since time immemorial in the traditional farming system for nutrient cycling, providing shade and getting multiple services (both products and services) through optimizing the available land area [38]. In the Terai region, all available land areas can be utilized for multiple purposes, and in a multistory system [3] in which farmers utilize spare land planting variety of ornamental plants there is higher plant diversity, as noted. Moreover, due to the larger size of home gardens in the Terai region, people in Terai tend to grow diverse species including ornamental plants and are in favor of decorating their home surroundings as well. On the contrary, in midhills, people focus on seasonal fruits species, especially on horticulture and vegetables in their limited and available land which have a direct link with the food security-lesser productivity per unit area in the midhills than in Terai [1]. Findings reveal that the promotion of horticulture and timber production could be more yielding in a hilly region where cereals and ornamental plants could better thrive in the Terai. This finding provides insight for plausible decision-making.

Moreover, ornamental plants are linked with the cultural and traditional believes of the people for worshipping God or Goddess as the flowers or other parts of plants are used for rituals since time immemorial in the Nepalese society. This may be the reason that these species occupy less space and can be grown easily anywhere in and around the house or a rooftop or in small pots at home space. Additionally, the Terai region is mostly colonized by the migration from midhills and formed a mosaic of cultural integrating places [1]; as a result, the residents in the Terai grow or introduce a new variety of plants as per their customary experience, which resulted in a higher diversity of plants especially of ornamental value. The results demonstrate that ornamental plants are the most preferred in both regions, although the proportion in Terai is relatively high due to the demographic and cultural diversity of the society in the region. Therefore, traditional practices and demographic factors should be duly considered for promoting or enhancing the agroforestry system for the benefit of people and the planet. Correspondingly, the trees providing fruits are also well maintained in both regions through the higher proportion found in the midhills region. In comparison to the midhills, the Terai area has more medicinal and traditional plants of religious significance (Figure 5). Fruits, fodder, and timber species are integrated slightly higher in the midhill region than in the Terai region. This reveals that the stall feeding livestock-based livelihood option and fuelwood-dependent energy supply for cooking are still prevalent and more prominent in the upland area than the low land of Province 5 of Nepal. A similar result was reported by the finding of the latest national census that still two-thirds of the population relies on fuelwood for household energy supply and most of them are from mountainous areas [1]. Furthermore, we observed during data collection that ornamental plants are nearly always available in every household, even if the houses lack the space to cultivate other plants appropriate for both ecological zones (Figure 5). These results suggest that the livestock-based agroforestry system could thrive in the midhills for enhancing better livelihood options of the farmers in this region.

The higher composition of fodder and timber species in midhill than Terai regions might be due to the fact that people in midhills involve in livestock husbandry with a stall feeding system due to uneven terrain [27] to allow livestock to graze in the fields more than Terai people do. As a result, people used to grow more diversified fodder plants and woody species for household fueling (fuelwood) and construction purposes [38]. This is also supported by the latest national census that the prime energy source for households in hilly regions is fuelwood and the main economic option is animal husbandry in Nepal [1]. A study reported that hill farmers are less relying on the forest while adopting an improved agroforestry system [4]. A similar reason could be valid for construction material is that midhill farmers have limited alternatives of wood for construction purposes due to availability and affordability reasons more than the options available in the case of Terai of Nepal.

The Shannon and Simpson indices are higher in Terai than in the midhill region, but no statistically significant differences are observed (Figure 6). However, almost the same BDI $h$ was obtained for both regions of the study. This indicates the higher species richness which is due to the high number of species in Terai. This result is consistent with the findings of other studies $[3,34]$. Moreover, it is found from the interview and observations that most of the people in midhills are attached to the livelihood option of animal husbandry and allow their livestock to graze and stall feed. The studies have shown that there is a significant increase in the richness or abundance of native plants with grazing protection in the midhills as a form of community forest whereas most of the people used to rear and graze livestock in those areas. Regulating such a forest management system nudges local farmers to raise fodder plants in their private land, which also facilitates the tree-agriculture crops interaction [27]. Regeneration and subsequent self-thinning of mulga (Acacia aneura) were promoted with grazing protection [39] in the case of Terai and therefore forest condition also improves and species diversity multiplies. However, the results indicate that Terai and midhills have almost equal dominant species, species diversity, and utilization diversity in the home garden of the agroforestry system maintained in Terai and midhills regions of Nepal. 
Overall, multiple benefits from home garden are observed worldwide as noted (Figure 5). Similar results were documented from the study on different agroforestry systems across the region. Moreover, properly managed agroforestry systems can harbor a high level of species diversity and higher options of benefits in multiple sectors. A small area of land can be utilized to contain a variety of plants in agroforestry which have several benefits [40], such as (a) diversified income, (b) cleaner air and water, (c) improved soil health, (d) safe and healthy food, (e) energy conservation, (f) bioenergy production, and (g) sustainable farms, ranches, and woodlands [38]. Another study highlighted the importance of home gardens as social and cultural spaces where knowledge related to agricultural practices and households' income and livelihood improves [5]. Moreover, the agroforestry system could be the best option to cope with the global environmental problem-climate change-with local action without compromising food security and without compromising the ethnobotany of indigenous people [24]. Therefore, the agroforestry system should be promoted for local to global benefits across the region including in Nepal. In short, the results may provide a glimpse of the vegetation community assemblage in the home garden-a typical example of the agroforestry system of Nepal giving insight into agroforestry policy guidance in species preferences based on the ecological, economical, and sociocultural environment.

\section{Conclusion}

More than 130 agroforestry species were recorded in both ecological regions. The relative value of the widely used diversity indices indicates that reasonably high plant diversity in the home garden is retained by farmers in both the Terai and the midhill regions of Nepal. However, neither the diversity of species nor the diversity of consumption within regions varied significantly. This indicates that plant diversity in the home garden of the two ecological regions is a common trend of species diversity, but the distribution of the species is different. However, different varieties of different plant species are growing in the home garden in Terai and midhill regions based on ecological differences. The midhill farmers prefer more fruits, fodder, and timber plants whereas Terai farmers choose go-to decorative and religious plants in their home garden in central Nepal. This finding may provide insight into agroforestry policy guidance in species preferences based on the ecological, economical, and sociocultural surroundings in the agroforestry system-home garden-a typical example of the agroforestry system of Nepal.

\section{Data Availability}

Data are available as supplementary material to the manuscript (Annex S1). Further disaggregated data can be obtained upon personal request to the corresponding author.

\section{Conflicts of Interest}

The authors declare that there are no conflicts of interest associated with the manuscript or data used for the study.

\section{Authors' Contributions}

All authors contributed equally to shaping this study but with differential roles.

\section{Acknowledgments}

The authors are in debt to Prakash Chandra Aryal for providing feedback on the preliminary manuscript. The authors thank Ms. Dikshya Devkota, the University of Illinois at Urbana-Champaign, USA, for English proofing and encouragement. Thanks are due to the local people from respective study sites for their cordial coordination and volunteer involvement during data collection.

\section{Supplementary Materials}

The table presents species name, belonging family, and the primary uses of the species found in the agroforestry system in two ecological regions of Nepal. The list of species in the table is based on the documentation during the field data survey-October and November. However, the agriculture species may vary in the account of other seasons. (Supplementary Materials)

\section{References}

[1] CBS, Population Atlas of Nepal, Central Bureau of Statistics, Kathmandu, Nepal, 2014.

[2] P. K. R. Nair, "Classification of agroforestry systems," Agroforestry Systems, vol. 3, no. 2, pp. 97-128, 1985.

[3] T. U. Waktola and K. Fekadu, "Adoption of coffee shade agroforestry technology and shade tree management in gobu seyo district, east wollega, oromia," Advances in Agriculture, vol. 2021, Article ID 8574214, 13 pages, 2021.

[4] D. Paudel, K. R. Tiwari, N. Raut et al., "Which agroforestry practice is beneficial? A comparative assessment of the traditional and the improved agroforestry techniques in the midhills of Nepal," Advances in Agriculture, vol. 8, 2021.

[5] G. Galluzzi, P. Eyzaguirre, and V. Negri, "Home gardens: neglected hotspots of agro-biodiversity and cultural diversity," Biodiversity \& Conservation, vol. 19, no. 13, pp. 3635-3654, 2010.

[6] M. M. Labata, E. C. Aranico, A. C. E. Tabaranza, J. H. P. Patricio, and R. F. J. Amparado, "Carbon stock assessment of three selected agroforestry systems in Bukidnon, Philippines," Advances in Environmental Sciences, vol. 4, no. 1, pp. 5-11, 2012.

[7] IPCC, Climate Change 2001: The Scientific Basis. Contribution of Working Group 1 to the Third Assessment Report of the IPCC, Cambridge University Press, Cambridge, MA, USA, 2001.

[8] R. Kindt, A. Degrande, L. Turyomurugyendo, C. Mbosso, P. Van Damme, and A. J. Simons, "Comparing species richness and evenness contributions to on-farm tree diversity for data sets with varying sample sizes from Kenya, Uganda, Cameroon, and Nigeria with randomized diversity profiles," Proceedings of the IUFRO Conference on Forestry Biometry, Modelling and Information Science, June 2001, University of Greenwich, London, UK.

[9] D. P. Garity, "Agroforestry and the achievement of the millennium development goals," Agroforestry Systems, vol. 61, pp. 5-17, 2004. 
[10] A. K. Acharya and N. Kafle, "Land degradation issues in Nepal and its management through agroforestry," Journal of Agriculture and Environment, vol. 10, pp. 133-143, 2009.

[11] A. S. Carter and D. A. Gilmour, "Increase in tree cover on private farm land in Central Nepal," Mountain Research and Development, vol. 9, no. 4, pp. 381-391, 1989.

[12] R. R. B. Leakey, G. J. Martin, and A. L. Agama, "The evolution of agroforestry systems," Cultivating Trees, vol. 5, 1999.

[13] J. H. Zhang, Z. A. Su, and G. C. Liu, "Effects of terracing and agroforestry on soil and water loss in hilly areas of the Sichuan Basin, China," Journal of Mountain Science, vol. 5, no. 3, pp. 241-248, 2008.

[14] N. P. Chaudhary and G. Chaudhary, "Popular culture on farmland: farmer's experience from Uttar Pradesh," Environmental, Forestry Bulletin, vol. 12, no. 1, 2012.

[15] R. P. Neupane, K. R. Sharma, and G. B. Thapa, "Adoption of agroforestry in the hills of Nepal: a logistic regression analysis," Agricultural Systems, vol. 72, no. 3, pp. 177-196, 2002.

[16] S. Khanal, "Contribution of agroforestry in biodiversity conservation and rural needs fulfillment," M.Sc Thesis, Tribhuvan University, Institute of Forestry, Kirtipur, Nepal, 2011.

[17] L. Karyono, "Home garden in Java: their structure and function," in Tropical Home Gardens, K. Landauer and M. Brazil, Eds., pp. 138-146, The United Nations University, Tokyo, Japan, 1990.

[18] E. C. M. Fernandez and P. K. R. Nair, "An evaluation of the structure and functions of tropical home gardens," Agricultural Systems, vol. 21, no. 4, pp. 279-310, 1986.

[19] P. Eyzaguirre and O. Linares, Home-gardens and Agro-Biodiversity, Smithsonian Books, Washington, DC, USA, 2004.

[20] F. Montagnini and P. K. R. Nair, "Carbon sequestration: an underexploited environmental benefit of agroforestry systems," Agroforestry Systems, vol. 61-62, no. 1-3, pp. 281-295, 2004.

[21] B. N. Regmi and B. Vickers, "Problems and challenges in the implementation of suggested improvements to fodder management strategies in the field through local farmer groups," Proceedings of the National Workshop on Improved Strategies for Identifying and Addressing Fodder Deficits in the Midhills of Nepal, Nepal Agroforestry Foundation, Amarabati Marga, Nepal, 2000.

[22] R. Khadka, "The transition from slash and burn (Khoriya) farming to permanent agroforestry in the middle hills of Nepal; an analysis of costs, benefits, and farmers' adoption," M.Sc Thesis, Department of International Environment and Development Studies, Norway, 2010.

[23] A. Dhakal, G. Cockfield, and T. N. Maraseni, Agroforestry Based Farming System, Farm Characteristics, and Climate Change: A Study of Dhanusha District, Nepal, The University of Southern Queensland, Queensland, Australia, 2012.

[24] S. M. Amatya, E. Cedamon, and I. Nuberg, Agroforestry Systems and Practices in Nepal-Revised Edition, Agriculture and Forestry University, Rampur, Nepal, 2018.

[25] D. Paudel, K. R. Tiwari, N. Raut, B. K. Sitaula, and P. Paudel, "Agroforestry practices in midhills of Nepal from gender perspective," Open Journal of Forestry, vol. 9, no. 4, pp. 323-340, 2019.

[26] DHM, Observed Climate Trend Analysis in the Districts and Physio-Graphic Regions of Nepal (1971-2014), Department of Hydrology and Meteorology, Government of Nepal, Kathmandu, Nepal, 2017.

[27] H. P. Pandey, I. E. Maaren, K. K. Shah, and T. N. Maraseni, "Response of topographic and biodiversity variables on biomass and carbon density in community forests of himalayan foot-hills," Journal of Forest and Livelihood, vol. 19, pp. 51-65, 2020.

[28] R Core Team, R: A Language and Environment for Statistical Computing, R Foundation for Statistical Computing, Vienna, Austria, 2018.

[29] J. Pearce and B. Derrick, "Preliminary testing: the devil of statistics?" Reinvention: An International Journal of Undergraduate Research, vol. 12, no. 2, 2019.

[30] P. Kerkhoff, "Measuring biodiversity of ecological communities," Ecology Lab. Biology, vol. 229, pp. 1-2, 2010.

[31] A. E. Magurran, Measuring Biological Diversity, Blackwell Publishing, Hoboken, NJ, USA, 2004.

[32] P. J. Somerfield, K. R. Clarke, and R. M. Warwick, "Simpson index," Ecological Indicators, Plymouth Marine Laboratory, Plymouth, UK, pp. 3252-3255, 2008.

[33] I. F. Spellerberg, "Shannon-Wiener index," Ecological Indicators, Lincoln University, Lincoln, New Zealand, pp. 3249-3252, 2008.

[34] S. Sunwar, "Home gardens in Province 5 Nepal: opportunities and challenges for on-farm management of agro-biodiversity," M.Sc Thesis, Uppsala University, Uppsala, Sweden, 2003.

[35] N. L. Devi and A. K. Das, "Diversity and utilization of tree species in Meitei homegardens of Barak valley, Assam," Journal of Environmental Biology, vol. 34, pp. 211-217, 2013.

[36] J. M. Roshetko, M. Delaney, K. Hairiah, and P. Purnomosidhi, "Carbon stocks in Indonesian home garden systems: can the smallholder system be targeted for increased carbon storage?" American Journal of Alternative Agriculture, vol. 17, no. 2, pp. 138-148, 2002.

[37] J. E. M. Arnold and M. R. Pérez, "Can non-timber forest products match tropical forest conservation and development objectives?" Ecological Economics, vol. 39, no. 3, pp. 437-447, 2001.

[38] K. K. Shah, B. Modi, H. P. Pandey et al., "Diversified crop rotation: an approach for sustainable agriculture production," Advances in Agriculture, vol. 2021, Article ID 8924087, 9 pages, 2021.

[39] R. J. Fensham, J. L. Silcock, and J. M. Dwyer, "Plant species richness responses to grazing protection and degradation history in a low productivity landscape," Journal of Vegetation Science, vol. 22, no. 6, pp. 997-1008, 2011.

[40] USDA, Working Trees for Agriculture, United States Development Agency, USDA National Agroforestry Center (NAC), Lincoln, NE, USA, 2012. 